\title{
UV-C Irradiation Affects Quality, Antioxidant Compounds and Activity of Musa AAA Berangan
}

(Penyinaran UV-C Mempengaruhi Kualiti, Sebatian dan Aktiviti Antioksidan Musa AAA Berangan)

\author{
Phebe Ding*, MuHAmmad Firdaus Rosli \& NuR AyUni MAHASSAN
}

\begin{abstract}
A study to determine the effects of ultraviolet-C $(U V-C)$ irradiation on fruit quality, antioxidant compounds and activities of Musa AAA Berangan was carried out. The mature green fruits were exposed to UV-C doses of 0, 0.01, 0.02, 0.03 and 0.04 $\mathrm{kJ} / \mathrm{m}^{2}$ and allowed to ripen at $25 \pm 2^{\circ} \mathrm{C}$ for 5 days. Peel and pulp color, water loss, firmness, soluble solids concentration (SSC), titratable acidity, $p H$, vitamin $C$, total phenolic contents (TPC) and antioxidant activity (assay using ferric-reducing antioxidant power (FRAP), 1,1-diphenyl-2-picrylhydrazyl (DPPH) and 2,2'-azinobis-(3-ethyl-benzothiazoline-6-sulfonic acid) (ABTS) free radical-scavenging) were analyzed at day 0, 1, 3 and 5 after ripening. The peel color $\left(L^{*}, C^{*}\right.$ and $\left.h^{\circ}\right)$ of Berangan banana decreased as UV-C irradiation dose increased. UV-C irradiated fruit has lower water loss, firmer pulp and lower SSC than control. The fruit could undergo normal ripening albeit the quality of fruit has been affected by UV-C irradiation. There was significant interaction between UV-C radiation $x$ day after ripening on TPC of Berangan banana. Fruit irradiated with UV-C showed significant higher of TPC as compared with control at later stage of ripening. Antioxidant activities measured with the three assays showed a significant decrease as ripening progressed. The results of this study showed that UV-C radiation as low as $0.01 \mathrm{~kJ} / \mathrm{m}^{2}$ is able to reduce water loss, slow down starch conversion and softening and enhanced TPC of Berangan banana.
\end{abstract}

Keywords: Firmness; peel and pulp color; soluble solids concentration; vitamin C

ABSTRAK

Suatu kajian untuk menentukan kesan iradiasi ultraungu-C (UV-C) ke atas kualiti, sebatian dan aktiviti antioksidan Musa AAA Berangan telah dijalankan. Buah yang hijau matang didedahkan kepada UV-C yang berdos 0, 0.01, 0.02, 0.03 dan $0.04 \mathrm{~kJ} / \mathrm{m}^{2}$ dan dibiarkan ranum pada $25 \pm 2^{\circ} \mathrm{C}$ selama 5 hari. Warna kulit dan isi, kehilangan air, kekerasan isi, kepekatan pepejal terlarut (SSC), keasidan tertitrat, $p H$, vitamin $C$, jumlah kandungan fenolik (TPC) dan aktiviti antioksidan (asai menggunakan kuasa antioksidan ferik-penurunan (FRAP), 1,1-difenil-2-pikrihidrazil(DPPH) dan penggarut-radikal bebas asid 2,2'-azinobis-(3-etil-benzotiazolin-6-sulfonik) (ABTS)) dianalisis pada hari 0, 1, 3 dan 5 selepas peranuman. Warna kulit $\left(L^{*}, C^{*}\right.$ and $\left.h^{\circ}\right)$ pisang Berangan berkurangan dengan peningkatan dos UV-C. Buah yang diiradiasi UV-C menunjukkan kehilangan air yang lebih rendah, isi yang lebih keras dan SSC yang lebih rendah daripada kawalan. Peranuman buah adalah normal walaupun kualiti buah telah dipengaruhi oleh iradiasi UV-C. Terdapat interaksi bererti antara radiasi UV-C $x$ hari selepas peranuman pada TPC pisang Berangan. Buah yang diiradiasi UV-C menunjukkan pertambahan TPC yang bererti berbanding dengan kawalan pada peringkat akhir peranuman. Aktiviti antioksidan yang diukur dengan ketiga-tiga asai menunjukkan pengurangan yang bererti sepanjang peranuman. Keputusan kajian ini mendedahkan bahawa iradiasi UV-C serendah $0.01 \mathrm{~kJ} / \mathrm{m}^{2}$ mampu mengurangkan kehilangan air, melambatkan pertukaran kanji dan pelembutan, serta meningkatkan TPC pisang Berangan.

Kata kunci: Kekerasan; kepekatan pepejal terlarut; vitamin C; warna kulit dan isi

\section{INTRODUCTION}

Recently, the usage of ultraviolet-C (UV-C) as one of the postharvest treatment has attracted great attention among researchers as it can extend shelf life of several fresh fruits and vegetables. Furthermore, it is safe to use and environmental friendly with no residue exposure issue. Tomatoes treated with UV-C irradiation showed an increase of fruit firmness by inhibiting the activity of cell wall degrading enzymes (Bu et al. 2013). The ripening of strawberry was delayed with longer postharvest life as UV-C treatment caused higher production of polyamines and led to reduce production of ethylene and action (Pombo et al. 2009). Low ethylene production and action decreased the activity of cell wall-degrading enzymes and thus delay strawberry ripening.

Postharvest treatments given to horticultural produce are a kind of abiotic stress. This stress may affect the levels of secondary metabolites in crop tissues by affecting pathways involved in the biosynthesis of three principal groups: Terpenes, phenolics and nitrogen containing compounds (Cisneros-Zevallos 2003). These compounds are often regarded as an antioxidant, which acts as a 
protective mechanism against oxidative compounds. UV-C irradiation increased the total phenols and total flavonoids of Haden mango as compared to control (Gonzalez-Aguilar et al. 2007). In blueberries, UV-C irradiation increased antioxidant activity, phenolics and total anthocyanin of fruit (Wang et al. 2009).

In Europe, UV-C irradiation technology has been used in industry as postharvest treatment. However, there is lack of study on the effects of UV-C irradiation on local fruits. In view of the potential usage of UV-C as postharvest treatments, it is high time to investigate the effects of UV-C on Malaysian's fruit. Banana is one of the most consumed fruits globally while Berangan banana is local variety and most popular among Malaysian. Unfortunately, it has short shelf life with fast starch conversion into sucrose and leads to firmness reduction (Ding 2008). From the literature it is hypothesized that UV-C irradiation could retain fruit quality during ripening. Thus, this study was carried out to examine quality characteristics, antioxidant compounds and activities of Berangan banana after irradiated with UV-C.

\section{MATERIALS AND METHODS}

\section{FRUIT SOURCES AND UV-C IRRADIATION}

Mature green Berangan banana were purchased from a wholesale market. Fruits that free from any form of mechanical injury, insect and pathogen damages were selected for the experiments. Fruits were irradiated with UV-C light (30 watt, $90 \mathrm{~cm}$ length) from a distance of 30 $\mathrm{cm}$ in an enclosed chamber. The radiation intensity used was 0 (control), 0.01, 0.02, 0.03 and $0.04 \mathrm{~kJ} / \mathrm{m}^{2}$. Mirrors were fitted to all sides of the chamber to ensure good spreading of the light from the lamp to the fruits. After irradiation, the banana was initiated to ripening by using $5 \mathrm{~mL} / \mathrm{L}$ of ethylene for $24 \mathrm{~h}$ at $25 \pm 2^{\circ} \mathrm{C}$. After $24 \mathrm{~h}$ of ripening initiation, the fruits were placed in $25 \pm 2{ }^{\circ} \mathrm{C} / 75 \%$ relative humidity room for ripening process. Three banana fingers from each irradiation dose at ripening day 0 (before ripening initiation), 1, 3 and 5 (after ripening initiation) were selected randomly for analysis.

\section{DETERMINATION OF FRUIT QUALITY}

Changes in the color of banana peel and pulp were measured using a chroma meter (Minolta CR-400, Japan). The values of $L^{*}, C^{*}$ and $h^{o}$ were taken randomly at the stem end, mid region and floral end of a fruit face. After peel color determination, the peel was removed and pulp color of the banana was measured at the spots as peel. The $L^{*}$ values indicate lightness of the color, which range from 0 (dark) to 100 (white). The $C^{*}$ values indicate the saturation of the color. The $h^{\circ}$ values of $0^{\circ}, 90^{\circ}, 180^{\circ}$ and $270^{\circ}$ is corresponding to the red, yellow, green and blue color, respectively.

The water loss during ripening was determined by the weight differences at days $0,1,3$ and 5, which were then compared with day 0 . The reading was expressed in percentage (fresh weight basis). Pulp firmness was evaluated using a computer-controlled Instron 5543 Material Testing Machine (Canton, MA, USA). The Instron was used simultaneously with an Instron Merlin software version M12-13664-EN. Banana pulp was subjected to a puncture test at a constant speed of $20 \mathrm{~mm} / \mathrm{min}$, using a 6 $\mathrm{mm}$ diameter plunger probe. Force formation curves were recorded and firmness (as represented by the slope newton $(\mathrm{N}) / \mathrm{mm}$ of the linear section of the force-deformation curve) was used as the indicator of textural property.

For soluble solids concentration (SSC), $10 \mathrm{~g}$ of fruit was macerated and the tissue was homogenized with 40 $\mathrm{mL}$ of distilled water by using a kitchen blender. After filtering with cotton wool, the filtrate was measured using a refractometer (Model N1, Atago Co., Japan) to obtain the $\%$ SSC. The readings were corrected to a standard temperature of $20^{\circ} \mathrm{C}$ by adding $0.28 \%$ to obtain $\%$ SSC at $27^{\circ} \mathrm{C}$.

The remainder of the filtrate from the SSC determination was used to determine titratable acidity (TA) and pH. TA was determined by titrating with $0.1 \mathrm{~mol} / \mathrm{L} \mathrm{NaOH}$ using $1 \%$ phenolphtalein as an indicator. The results were calculated as a percentage malic acid. $\mathrm{pH}$ of filtrate was measured using a glass electrode (Crison Micro pH 2000, Spain).

As for vitamin $\mathrm{C}$ content, $10 \mathrm{~g}$ banana pulp was homogenized with $3 \%$ cold $\mathrm{HPO}_{3}$ using a kitchen blender. The volume was made up to $50 \mathrm{~mL}$ and filtered with cotton wool. Then, $5 \mathrm{~mL}$ of the filtrate was titrated with 2 , 6-dichlorophenol-indophenol solution to a pink color. The vitamin $\mathrm{C}$ content was determined according to Ranganna (1977) method.

\section{DETERMINATION OF TOTAL PHENOLIC CONTENTS (TPC) AND ANTIOXIDANT ACTIVITY}

At each analysis days, fresh fruit pulp sample was cut into small pieces and frozen with liquid nitrogen. Then, the sample was freeze-dried with a freeze dryer (Martin Christ BETA 1-8 LD, Germany) for two days. The dried samples were pounded using a pebble and pestle into fine powder and stored in a dark container at $-20^{\circ} \mathrm{C}$ prior to analysis. One gram of the ground sample was extracted with $50 \mathrm{~mL}$ $80 \%$ methanol solution at room temperature on an orbital shaker set at $180 \mathrm{rpm}$. The mixture was centrifuged at 2000 rpm for $30 \mathrm{~min}$. After that, the extract was used for TPC and antioxidant activity determination.

TPC of the crude extract was determined by using Folin-Ciocalteu assay method described by Alothman et al. (2009) with some modifications. $1.5 \mathrm{~mL}$ of $10 \%$ FolinCiocalteu assay and $1.2 \mathrm{~mL} \mathrm{6 \%} \mathrm{sodium} \mathrm{bicarbonate} \mathrm{were}$ mixed with $300 \mu \mathrm{L}$ crude extract. The solution was allowed to stand for $1 \mathrm{~h}$ in the dark at $25 \pm 2^{\circ} \mathrm{C}$. The absorbance was measured at $765 \mathrm{~nm}$ using a spectrophotometer (S1200, England) in triplicates. A calibration curve was prepared using a standard solution of gallic acid $(0.01-0.11 \mathrm{mg} / \mathrm{mL}$, $\left.\mathrm{R}^{2}=0.9774\right)$ in $80 \%$ methanol, giving an absorbance range of $0.123-1.118$. The results were expressed as $\mathrm{mg}$ gallic acid equivalents (GAE)/g banana dry weight. 
The antioxidant activity of UV-C treated banana was studied by performing ferric reducing antioxidant power (FRAP) assay, a method adopted from Alothman et al. (2009) with some modifications. The FRAP reagent was prepared by mixing $2.5 \mathrm{~mL}$ TPTZ (2, 4, 6-tripyridyl-striazine) solution, $2.5 \mathrm{~mL}$ ferric chloride and $25 \mathrm{~mL}$ acetate buffer (pH3 .6). The FRAP reagent was pre-warmed at $37^{\circ} \mathrm{C}$ for $4 \mathrm{~min}$ before being added to $40 \mu \mathrm{L}$ aliquots of extract sample. The mixture was then incubated at $37^{\circ} \mathrm{C}$ for 1 h. The absorbance was determined at $593 \mathrm{~nm}$, using a spectrophotometer (S1200, England) over three times. A calibration curve was prepared using a standard solution of Trolox (6-hydroxy-2,5,7,8-tetrametychroman-2-carboxylic acid) $\left(400-2000 \mu \mathrm{mol} / \mathrm{L}, \mathrm{R}^{2}=0.9077\right)$ in $80 \%$ methanol giving an absorbance range of $0.245-0.742$. FRAP values were expressed as $\mu \mathrm{mol}$ Trolox/g banana dry weight.

The antioxidant activity of the fruit extracts was also studied by evaluating the free-radical-scavenging effect on 1,1-diphenyl-2-picrylhydrazyl (DPPH) radical, a method adopted from Alothman et al. (2009) with some modifications. $100 \mu \mathrm{L}$ extract was mixed with $250 \mu \mathrm{L}$ methanolic DPPH solution and $2 \mathrm{~mL}$ of $80 \%$ methanol. The mixture was shaken and allowed to stand for $30 \mathrm{~min}$ at $25 \pm 2^{\circ} \mathrm{C}$. The absorbance readings were taken at $517 \mathrm{~nm}$ using a spectrophotometer (S1200, England). A calibration curve was prepared using a standard solution of Trolox $\left(160-800 \mu \mathrm{mol} / \mathrm{L}, \mathrm{R}^{2}=0.906\right)$ in $80 \%$ methanol giving an absorbance range of $0.648-0.267$. The results were expressed in $\mu \mathrm{mol}$ Trolox/g banana dry weight.

The antioxidant activity of UV-C treated banana was also determined by using 2,2-azinobis (3-ethylbenzothiazoline-6-sulfonic acid) $\left(\mathrm{ABTS}^{\circ+}\right)$ free-radicalscavenging following the procedure described by Shan et al. (2005) with some modification. Seven mM of ABTS and $2.45 \mathrm{mM}$ of $\mathrm{K}_{2} \mathrm{O}_{8} \mathrm{~S}_{2}$ were mixed and incubated for $16 \mathrm{~h}$ in the dark at $25 \pm 2^{\circ} \mathrm{C}$ before use to generate $\mathrm{ABTS}^{\circ+}$ radical cation. The $\mathrm{ABTS}^{\circ+}$ solution was diluted with distilled water to give an absorbance at $734 \mathrm{~nm}$ of $0.700 \pm 0.005$. Then, 3.9 mL of the $\mathrm{ABTS}^{\circ+}$ solution was mixed thoroughly with 100 $\mu \mathrm{L}$ extract sample and left to stand for $6 \mathrm{~min}$ at $25 \pm 2^{\circ} \mathrm{C}$ in the dark. The absorbance was measured at $734 \mathrm{~nm}$ by using a spectrophotometer (S1200, England). A calibration curve was prepared using a standard solution of Trolox (200-1000 $\left.\mu \mathrm{mol} / \mathrm{L}, \mathrm{R}^{2}=0.961\right)$ in $80 \%$ methanol giving an absorbance range of $0.565-0.051$. The results were expressed as $\mu \mathrm{mol}$ Trolox/g fruit dry weight.

\section{STATISTICAL ANALYSIS}

The experimental design was a randomized complete block design with a factorial arrangement of treatments (5 levels of radiation dose $\times 4$ days of ripening) and replicated thrice. Data were analyzed using analysis of variance while means was separated using least significant difference (LSD) at $p \leq 0.05$. The Pearson's correlation analysis was performed to correlate the fruit quality characteristics, as well as antioxidant compounds and activities of the fruit. All statistical analysis was carried out using SAS 9.1.

\section{RESULTS}

The $L^{*}, C^{*}$ and $h^{\circ}$ values of Berangan banana peel decreased as UV-C irradiation dose increased (Table 1). In contrast to peel, the pulp color of fruit was generally not affected by UV-C irradiation, except the $L^{*}$ values. As ripening progressed, both banana peel and pulp showed increases in $L^{*}$ and $C^{*}$ values while peel $h^{\circ}$ values decreased significantly from green (119.69) to yellow (88.20). The pulp $h^{\circ}$ values did not show any changes as the fruit ripened from Day 0 to 5 .

TABLE 1. Main and interaction effects of UV-C radiation and day after ripening on peel and pulp color $\left(L^{*}, C^{*}\right.$, and $\left.h^{\circ}\right)$ of Berangan banana

\begin{tabular}{|c|c|c|c|c|c|c|}
\hline \multirow{2}{*}{ Factors } & \multicolumn{3}{|c|}{ Peel color } & \multicolumn{3}{|c|}{ Pulp color } \\
\hline & $L^{*}$ & $C^{*}$ & $h^{\circ}$ & $L^{*}$ & $C^{*}$ & $h^{\circ}$ \\
\hline \multicolumn{7}{|c|}{ UV-C radiation dose $(\mathrm{U}), \mathrm{kJ} / \mathrm{m}^{2}$} \\
\hline 0.00 & $63.65 \mathrm{a}^{\mathrm{z}}$ & $36.99 \mathrm{a}$ & $115.08 \mathrm{a}$ & $71.02 \mathrm{a}$ & $30.65 \mathrm{a}$ & $94.38 \mathrm{a}$ \\
\hline 0.01 & $63.26 \mathrm{a}$ & $37.02 \mathrm{a}$ & $116.47 \mathrm{a}$ & $69.51 \mathrm{abc}$ & $30.54 \mathrm{a}$ & $93.43 \mathrm{a}$ \\
\hline 0.02 & $62.68 \mathrm{ab}$ & $36.70 \mathrm{a}$ & $115.26 \mathrm{a}$ & $70.42 \mathrm{ab}$ & $30.60 \mathrm{a}$ & $93.17 \mathrm{a}$ \\
\hline 0.03 & $61.69 \mathrm{~b}$ & $33.25 \mathrm{~b}$ & $106.36 \mathrm{~b}$ & $68.99 \mathrm{bc}$ & $30.36 \mathrm{a}$ & $92.78 \mathrm{a}$ \\
\hline 0.04 & $60.27 \mathrm{c}$ & $32.94 \mathrm{~b}$ & $106.08 \mathrm{~b}$ & $68.09 \mathrm{c}$ & $30.10 \mathrm{a}$ & $90.51 \mathrm{a}$ \\
\hline \multicolumn{7}{|c|}{ Day after ripening (D) } \\
\hline 0 & $56.38 \mathrm{~b}$ & $29.03 \mathrm{c}$ & $119.69 \mathrm{a}$ & $66.89 \mathrm{~b}$ & $25.86 \mathrm{c}$ & $93.60 \mathrm{a}$ \\
\hline 1 & $56.34 \mathrm{~b}$ & $30.32 \mathrm{c}$ & $118.51 \mathrm{a}$ & $67.62 \mathrm{~b}$ & $26.77 \mathrm{c}$ & $94.84 \mathrm{a}$ \\
\hline 3 & $66.57 \mathrm{a}$ & $41.26 \mathrm{~b}$ & $96.70 \mathrm{~b}$ & $72.03 \mathrm{a}$ & $33.47 \mathrm{~b}$ & $92.76 \mathrm{a}$ \\
\hline 5 & $68.34 \mathrm{a}$ & $45.70 \mathrm{a}$ & $88.20 \mathrm{c}$ & $71.89 \mathrm{a}$ & $35.69 \mathrm{a}$ & $90.22 \mathrm{a}$ \\
\hline \multicolumn{7}{|l|}{ Interaction } \\
\hline $\mathrm{Ux} \mathrm{D}$ & NS & NS & NS & NS & NS & NS \\
\hline
\end{tabular}


UV-C irradiation affected Berangan banana water loss with irradiated fruit showed significant lower water loss than the control (Table 2). Fruit irradiated with $0.01 \mathrm{~kJ} /$ $\mathrm{m}^{2} \mathrm{UV}-\mathrm{C}$ showed a lower water loss as compared to 0.02 , 0.03 and $0.04 \mathrm{~kJ} / \mathrm{m}^{2}$ dose. As expected, Berangan banana showed $7.37 \%$ of water loss as the fruit ripened from day 0 to 5 . The firmness of control fruit was much lower than UV-C irradiated fruit by about $25 \%$ (Table 2). SSC of Berangan banana was affected significantly by interaction between the radiation dose $\mathrm{x}$ day after ripening (Table 2). At ripening Day 1 and 3, the SSC of control fruit exceeds UV-C irradiated fruit (Figure 1). By ripening Day 5, fruit irradiated with $0.02 \mathrm{~kJ} / \mathrm{m}^{2} \mathrm{UV}-\mathrm{C}$ has lower SSC than other treatment of fruit. Dose of $0.01 \mathrm{~kJ} / \mathrm{m}^{2} \mathrm{UV}-\mathrm{C}$ caused lower $\mathrm{TA}$ in Berangan banana as compared with control (Table
2). For $\mathrm{pH}, 0.02$ and $0.03 \mathrm{~kJ} / \mathrm{m}^{2} \mathrm{UV}-\mathrm{C}$ dose irradiated fruit exhibited higher $\mathrm{pH}$ than control (Table 2). Both TA and $\mathrm{pH}$ showed a contradictory trend during ripening.

Among UV-C radiation dose, $0.01 \mathrm{~kJ} / \mathrm{m}^{2}$ enhanced vitamin $\mathrm{C}$ content in Berangan banana (Table 3). Unlike vitamin $\mathrm{C}$, there was significant interaction between UV-C radiation dose $\mathrm{x}$ day after ripening on TPC of Berangan banana (Table 3). However, no significant interaction was found in antioxidant activity of Berangan banana as evaluated using FRAP, DPPH and ABTS assays. Figure 2 shows the interaction effect of UV-C radiation dose on TPC of Berangan banana during fruit ripening. At ripening Day 0 , generally there was no significant difference in TPC among control and UV-C irradiated fruit. After a day of ripening, $0,0.01$ and $0.02 \mathrm{~kJ} / \mathrm{m}^{2} \mathrm{UV}-\mathrm{C}$ irradiated fruit has higher TPC

TABLE 2. Main and interaction effects of UV-C radiation and day after ripening on water loss, firmness, soluble solids concentration (SSC), titratable acidity (TA) and $\mathrm{pH}$ of Berangan banana

\begin{tabular}{|c|c|c|c|c|c|}
\hline Factors & $\begin{array}{c}\text { Water loss } \\
(\%)\end{array}$ & $\begin{array}{c}\text { Firmness } \\
(\mathrm{N})\end{array}$ & $\begin{array}{c}\mathrm{SSC} \\
(\% \mathrm{SSC})\end{array}$ & $\begin{array}{c}\mathrm{TA} \\
(\% \text { malic acid })\end{array}$ & $\mathrm{pH}$ \\
\hline \multicolumn{6}{|c|}{ UV-C radiation dose $(\mathrm{U}), \mathrm{kJ} / \mathrm{m}^{2}$} \\
\hline $\begin{array}{c}0 \\
0.01 \\
0.02 \\
0.03 \\
0.04\end{array}$ & $\begin{array}{l}4.30 \mathrm{a}^{\mathrm{z}} \\
2.48 \mathrm{c} \\
3.29 \mathrm{~b} \\
3.39 \mathrm{~b} \\
3.49 \mathrm{~b}\end{array}$ & $\begin{array}{l}9.68 \mathrm{~b} \\
12.85 \mathrm{a} \\
11.94 \mathrm{a} \\
11.88 \mathrm{a} \\
11.87 \mathrm{a}\end{array}$ & $\begin{array}{l}11.63 \mathrm{a} \\
10.85 \mathrm{~b} \\
11.07 \mathrm{~b} \\
10.95 \mathrm{~b} \\
10.91 \mathrm{~b}\end{array}$ & $\begin{array}{c}0.37 \mathrm{a} \\
0.34 \mathrm{~b} \\
0.36 \mathrm{ab} \\
0.35 \mathrm{ab} \\
0.35 \mathrm{ab}\end{array}$ & $\begin{array}{c}4.99 \mathrm{~b} \\
5.06 \mathrm{ab} \\
5.01 \mathrm{a} \\
5.12 \mathrm{a} \\
5.08 \mathrm{ab}\end{array}$ \\
\hline \multicolumn{6}{|c|}{ Day after ripening (D) } \\
\hline $\begin{array}{l}0 \\
1 \\
3 \\
5\end{array}$ & $\begin{array}{l}0.00 \mathrm{~d} \\
0.92 \mathrm{c} \\
5.27 \mathrm{~b} \\
7.37 \mathrm{a}\end{array}$ & $\begin{array}{c}24.87 \mathrm{a} \\
17.77 \mathrm{~b} \\
2.20 \mathrm{c} \\
1.73 \mathrm{c}\end{array}$ & $\begin{array}{c}3.11 \mathrm{~d} \\
4.93 \mathrm{c} \\
15.43 \mathrm{~b} \\
20.86 \mathrm{a}\end{array}$ & $\begin{array}{l}0.21 \mathrm{~d} \\
0.25 \mathrm{c} \\
0.52 \mathrm{a} \\
0.44 \mathrm{~b}\end{array}$ & $\begin{array}{l}5.63 \mathrm{a} \\
5.31 \mathrm{~b} \\
4.61 \mathrm{c} \\
4.66 \mathrm{c}\end{array}$ \\
\hline \multicolumn{6}{|l|}{ Interaction } \\
\hline $\mathrm{U} \times \mathrm{D}$ & NS & NS & $*$ & NS & NS \\
\hline
\end{tabular}

${ }^{\mathrm{z}}$ Different letters within columns and factors denote significant differences by LSD at $p \leq 0.05$

NS, * Non- significant or significant at $p \leq 0.05$

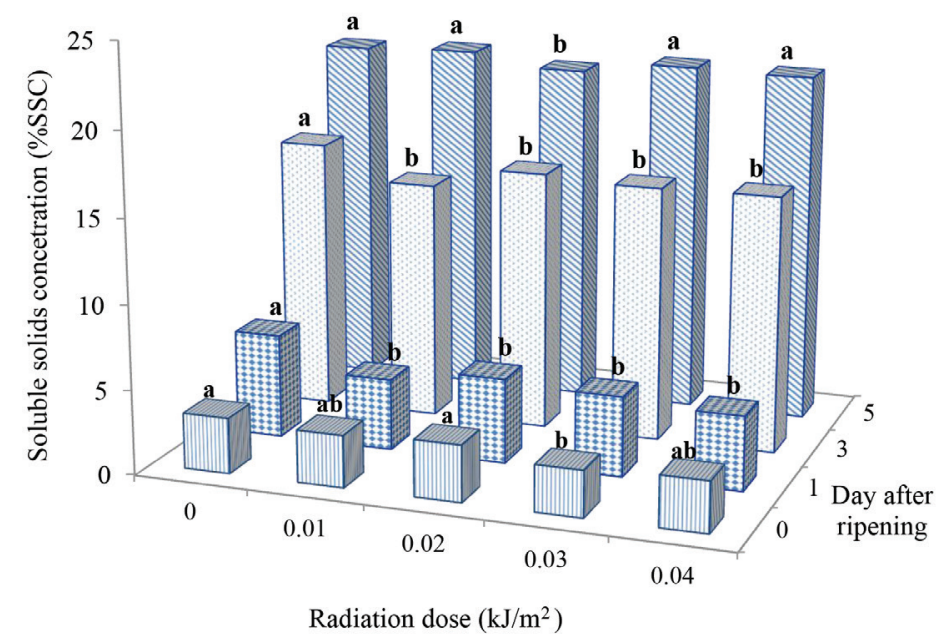

FIGURE 1. Effects of UV-C radiation $\mathrm{x}$ day after ripening on soluble solids concentration of Berangan banana. Means separations pertaining to each day after ripening followed by the same letters are not significantly different by LSD at $p \leq 0.05$ 
TABLE 3. Main and interaction effects of UV-C radiation and day after ripening on vitamin $\mathrm{C}$ content, total phenolic contents (TPC) and antioxidant activity (FRAP, DPPH and ABTS) of Berangan banana

\begin{tabular}{|c|c|c|c|c|c|}
\hline Factors & $\begin{array}{c}\text { Vitamin C } \\
\text { (mg 100/g fruit } \\
\text { FW) }\end{array}$ & $\begin{array}{c}\text { TPC } \\
\text { (mg GAE/g fruit } \\
\text { DW) }\end{array}$ & $\begin{array}{c}\text { FRAP } \\
(\mu \mathrm{mol} \text { Trolox/g fruit } \\
\text { DW })\end{array}$ & $\begin{array}{c}\text { DPPH } \\
(\mu \mathrm{mol} \text { Trolox/g fruit } \\
\text { DW })\end{array}$ & $\begin{array}{c}\text { ABTS } \\
(\mu \text { mol Trolox } / g \\
\text { fruit DW })\end{array}$ \\
\hline \multicolumn{6}{|c|}{ UV-C radiation dose $(\mathrm{U}), \mathrm{kJ} / \mathrm{m}^{2}$} \\
\hline $\begin{array}{c}0 \\
0.01 \\
0.02 \\
0.03 \\
0.04\end{array}$ & $\begin{array}{l}3.77 \mathrm{~b}^{\mathrm{z}} \\
4.51 \mathrm{a} \\
3.87 \mathrm{~b} \\
3.85 \mathrm{~b} \\
3.67 \mathrm{~b}\end{array}$ & $\begin{array}{c}2.88 \mathrm{bc} \\
3.39 \mathrm{a} \\
3.14 \mathrm{ab} \\
3.16 \mathrm{ab} \\
2.79 \mathrm{c}\end{array}$ & $\begin{array}{c}35.75 \mathrm{bc} \\
39.93 \mathrm{a} \\
38.94 \mathrm{ab} \\
38.32 \mathrm{ab} \\
33.90 \mathrm{c}\end{array}$ & $\begin{array}{c}28.31 \mathrm{a} \\
31.79 \mathrm{a} \\
28.12 \mathrm{~b} \\
29.13 \mathrm{ab} \\
25.62 \mathrm{~b}\end{array}$ & $\begin{array}{l}20.50 \mathrm{ab} \\
22.47 \mathrm{a} \\
21.96 \mathrm{a} \\
21.54 \mathrm{a} \\
19.23 \mathrm{~b}\end{array}$ \\
\hline \multicolumn{6}{|c|}{ Day after ripening (D) } \\
\hline $\begin{array}{l}0 \\
1 \\
3 \\
5\end{array}$ & $\begin{array}{l}4.46 \mathrm{a} \\
4.48 \mathrm{a} \\
3.99 \mathrm{~b} \\
2.81 \mathrm{c}\end{array}$ & $\begin{array}{l}3.88 \mathrm{a} \\
3.83 \mathrm{a} \\
3.16 \mathrm{~b} \\
1.42 \mathrm{c}\end{array}$ & $\begin{array}{l}46.34 \mathrm{a} \\
45.69 \mathrm{a} \\
35.33 \mathrm{~b} \\
22.12 \mathrm{c}\end{array}$ & $\begin{array}{l}36.48 \mathrm{a} \\
35.22 \mathrm{a} \\
23.17 \mathrm{~b} \\
19.51 \mathrm{c}\end{array}$ & $\begin{array}{l}27.41 \mathrm{a} \\
27.00 \mathrm{a} \\
20.12 \mathrm{~b} \\
10.02 \mathrm{c}\end{array}$ \\
\hline $\begin{array}{c}\text { Interactior } \\
\text { U x D }\end{array}$ & NS & $*$ & NS & NS & NS \\
\hline
\end{tabular}

${ }^{2}$ Different letters within columns and factors denote significant differences by LSD at $p \leq 0.05$

NS, * Non- significant or significant at $p \leq 0.05$

FW $=$ Fresh weight

DW $=$ Dry weight

FRAP $=$ Ferric reducing antioxidant power

DPPH $=1,1$-Diphenyl-2-picrylhydrazl radical-scavenging activity

ABTS $=2,2^{\prime}$, -Azino(bis-3-ethyl-benzothiozoline-6-sulfonic acid) radical-scavenging activity

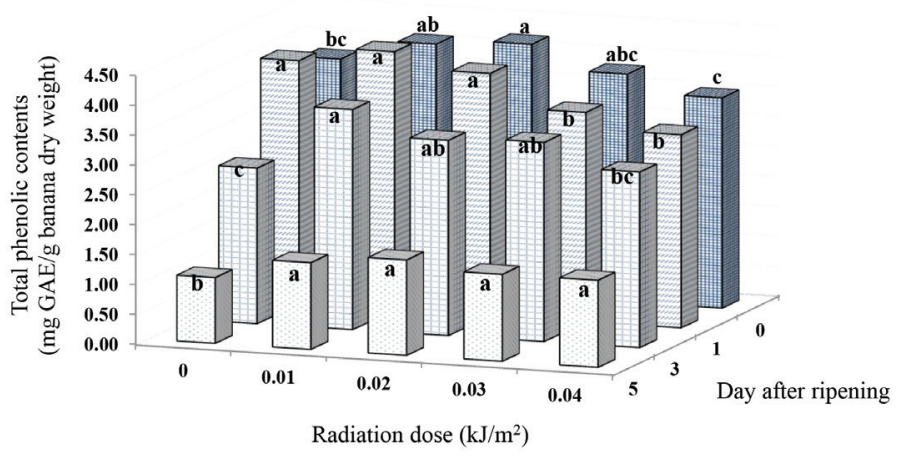

FIGURE 2. Effects of UV-C radiation $\mathrm{x}$ day after ripening on total phenolic contents of Berangan banana. Means separations pertaining to each day after ripening followed by the same letters are not significantly different by LSD at $p \leq 0.05$

than fruit exposed to 0.03 and $0.04 \mathrm{~kJ} / \mathrm{m}^{2}$. By ripening Day 3 , it is obvious that the TPC of control fruit was lower than fruit irradiated with $0.01,0.02$ and $0.03 \mathrm{~kJ} / \mathrm{m}^{2}$ of UV-C. By ripening Day 5 where the fruit is suitable for consumption, the TPC of control fruit was significant lower than fruit irradiated with UV-C. This indicated that fruit irradiated with UV-C has higher TPC although the content decreased as ripening day progressed. Or in other words, the TPC of Berangan banana was preserved by UV-C radiation.

After exposing to $0.01 \mathrm{~kJ} / \mathrm{m}^{2} \mathrm{UV}-\mathrm{C}$, the antioxidant activity of Berangan banana as evaluated using FRAP showed significant higher activity than control (Table 3 ). This followed by significant decrease when fruit irradiated with $0.04 \mathrm{~kJ} / \mathrm{m}^{2} \mathrm{UV}-\mathrm{C}$. When antioxidant activity of Berangan banana evaluated using DPPH, fruit irradiated with 0.02 and $0.04 \mathrm{~kJ} / \mathrm{m}^{2} \mathrm{UV}-\mathrm{C}$ showed significant lower activity than control and $0.01 \mathrm{~kJ} / \mathrm{m}^{2} \mathrm{UV}-\mathrm{C}$ (Table 3). A quite similar finding was also found in ABTS with lower activity when fruit irradiated with $0.04 \mathrm{~kJ} / \mathrm{m}^{2} \mathrm{UV}-\mathrm{C}$ as compared to other dosage (Table 3). Regardless of irradiation dose, antioxidant activities as assayed using FRAP, DPPH and ABTS decreased with ripening (Table 3).

\section{DISCUSSION}

In the present study, as ripening day progressed Berangan banana showed substantial changes in peel color (Table 1), firmness and SSC (Table 2). These changes are in 
TABLE 4. Correlation coefficients of vitamin C, total phenolic contents (TPC) and antioxidant activity (FRAP, DPPH and ABTS assays) of Berangan banana treated with different intensity of UV-C and allow ripening for 5 days

\begin{tabular}{|c|c|c|c|c|c|}
\hline & Vitamin C & ТPC & FRAP & DPPH & ABTS \\
\hline Vitamin C & - & & & & \\
\hline ТPC & $0.107^{\mathrm{ns}}$ & - & & & \\
\hline FRAP & $-0.005^{\mathrm{ns}}$ & $0.909 * *$ & - & & \\
\hline DPPH & $-0.080^{\text {ns }}$ & $0.613 * *$ & $0.674 * *$ & - & \\
\hline ABTS & $0.002^{\mathrm{ns}}$ & $0.921 * *$ & $0.930 * *$ & $0.717 * *$ & - \\
\hline
\end{tabular}

NS, ** Non- significant or highly significant at $\mathrm{P} \leq 0.05$

FRAP $=$ Ferric reducing antioxidant power

DPPH $=1,1$-Diphenyl-2-picrylhydrazl radical-scavenging activity

ABTS $=2,2^{\prime}$, -Azino(bis-3-ethyl-benzothiozoline-6-sulfonic acid) radical-scavenging activity

accordance to the findings reported by Ding et al. (2006) and Ding (2008) in Berangan banana. As compared to control, UV-C irradiated fruit has lower water loss, higher pulp firmness and lower SSC than control fruit (Table 2). Reducing water loss in UV-C irradiated fruit is beneficial where besides directly reduce financial loss due to weight loss, it also maintains fruit composition and metabolism of detached fruit (Rizzini et al. 2009). Firmness of Berangan banana was retained in UV-C treated fruit (Table 2). Similar finding was also found in tomato ( $\mathrm{Bu}$ et al. 2013) and strawberry (Pombo et al. 2009). The firmer tomato after UV-C irradiation was due to higher content of cellulose and acid-soluble pectin than control (Bu et al. 2013). UV-C irradiation also retarded cell wall disassembly of tomato pericarp and suppressed the transcription expression of PME2.1, Cell, PGcat and Expl genes and thus inhibited pectin methylesterase (PME), polygalacturonase (PG) and cellulose activities during storage. The literature on the effect of UV-C irradiation on enzymes associated with banana peel cell wall modification is lacking. However, the PME and PG activities of Berangan banana that dipped in $50^{\circ} \mathrm{C}$ hot water was lower than control fruit (Ding \& Amin 2013). This indicated PME and PG activities of Berangan banana is affected by postharvest treatment.

The effect of UV-C irradiation on SSC varied with fruit species. UV-C irradiation did not affect SSC of apple (Hagen et al. 2007) and tomato (Liu et al. 2009) but induced SSC accumulation in strawberry (Li et al. 2014). In present study, the effect of UV-C on SSC of Berangan banana differed from these researchers. The interaction results indicated that the SSC of control fruit was higher than UV-C irradiated fruit during initial of ripening. As ripening progressed to Day 5, fruit irradiated with $0.02 \mathrm{~kJ} / \mathrm{m}^{2}$ UV-C exhibited lower SSC. This indicated $0.02 \mathrm{~kJ} / \mathrm{m}^{2}$ UV-C radiation is able to slow down Berangan banana fruit metabolism. The increase of SSC is a common metabolic response in Berangan banana towards ripening where starch hydrolyzed to sucrose (Ding 2008).

In the present study, UV-C irradiation has caused TPC accumulation in Berangan banana as shown in Figure 2. The increase in TPC is a common response of the plant to stresses. The accumulation of TPC could be due to excessive lignification in response to the phytotoxic effect of the high UV-C dose. Phenolic compounds are the most important compound and major contributors to the antioxidant property in the fruits (Scalzo et al. 2005). This can be proven in this study where TPC correlated strongly with FRAP $(r=0.909)$ and ABTS $(r=0.921)$ and moderately with DPPH ( $r=0.613$ ) (Table 4). However, vitamin C did not correlate with TPC and antioxidant activities indicating vitamin $\mathrm{C}$ did not contribute to antioxidant activity in Berangan banana. This could probably due to low content of vitamin $C$ in Berangan banana. Antioxidant compounds and antioxidant activities of UV-C irradiated Berangan banana decreased as day after ripening progressed and showed lowest contents and activities by ripening Day 5 (Table 3). In terms of nutritional quality, this is not a good change as banana is eaten when it is fully ripen by ripening Day 5. However, from Figure 2, it is clear that fruit irradiated with UV-C contains higher TPC as compared to control fruit.

In conclusion, UV-C irradiation is a potential treatment to retain fruit quality. The only drawback in using UV-C irradiation is peel browning which affects visual quality of fruit. From Ding and Yap (2014) study, it was found that the lethal dose causing Berangan banana peel browning is $0.03 \mathrm{~kJ} / \mathrm{m}^{2} \mathrm{UV}-\mathrm{C}$. Thus, $0.01 \mathrm{~kJ} / \mathrm{m}^{2} \mathrm{UV}-\mathrm{C}$ irradiation is recommended to retain fruit quality and enhance TPC of Berangan banana. For further study, the effects of UV-C irradiation on pathogen disease will be carried out as UV-C has germicidal property which could replace the usage of agrochemicals in postharvest treatment.

\section{REFERENCES}

Alothman, M., Bhat, R. \& Karim, A.A. 2009. UV radiationinduced changes of antioxidant capacity of fresh-cut tropical fruits. Innovative Food Science and Emerging Technologies 10: $512-516$.

Bu, J., Yu, Y., Aisikaer, G. \& Ying, T. 2013. Postharvest UV-C irradiation inhibits the production of ethylene and the activity of cell wall-degrading enzymes during softening of tomato (Lycopersicon esculentum L.) fruit. Postharvest Biology and Technology 86: 337-345.

Cisneros-Zevallos, L. 2003. The use of controlled postharvest abiotic stresses as a tool for enhancing the nutraceutical content and adding-value of fresh fruits and vegetables. Journal of Food Science 68(5): 1560-1565.

Ding, P. \& Yap, S.L. 2014. Browning assessment methods and polyphenol oxidase in UV-C irradiated Berangan banana fruit. International Food Research Journal 21(4): 1667-1674. 
Ding, P. \& Amin, M. 2013. Hot water dip treatment affects cell wall degradation enzymes of Musa AAA Berangan. In abstracts book of The 2nd Southeast Asia Symposium on Quality Management in Postharvest Systems. December 3-6, Lane Xang Hotel, Vientiane, Lao PDR. pp. P-053.

Ding, P. 2008. Cellular structure and selected physico-chemical changes during ripening of Musa AAA 'Berangan'. Pertanika Journal of Tropical Agricultural Science 31(2): 217-222.

Ding, P., Ahmad, S.H., Abd. Razak A.R., Mohamed, M.T.M. \& Saari, N. 2006. Peel color of Musa AAA 'Berangan' and 'William Cavendish' during degreening. AgroSearch Research Bulletin 11(1): 1-4.

Gonzalez-Aguilar, G.A., Zavaleta-Gatica, R. \& TiznadoHernandez, M.E. 2007. Improving postharvest quality of mango 'Haden' by UV-C treatment. Postharvest Biology and Technology 45: 108-116.

Hagen, S.F., Borge, G.I.A., Bengtsson, G.B., Bilger, W., Berge, A., Haffner, K. \& Solhaug, K.A. 2007. Phenolic contents and other health and sensory related properties of apple fruit (Malus domestica Borkh. cv. Aroma): Effect of postharvest UV-B irradiation. Postharvest Biology and Technology 45: $1-10$.

Li, D., Luo, Z., Mou, W., Wang, Y., Ying, T. \& Mao, L. 2014. ABA and UV-C effects on quality, antioxidant capacity and anthocyanin contents of strawberry fruit (Fragaria ananassa Duch.). Postharvest Biology and Technology 90: 56-62.

Liu, L.J., Zabaras, D., Bennett, L.E., Aguas, P. \& Woonton, B.W. 2009. Effects of UV-C, red light and sun light on the carotenoid content and physical qualities of tomatoes during post-harvest storage. Food Chemistry 115: 495-500.

Pombo, M.A., Dotto, M.C., Martinez, G.A. \& Civello, P.M. 2009. UV-C irradiation delays strawberry fruit softening and modifies the expression of genes involved in cell wall degradation. Postharvest Biology and Technology 51: 141148.
Ranganna, S. 1977. Manual of Analysis of Fruit and Vegetable Products. New Delhi: Tata McGraw Hill Publishing Co. Ltd.

Rizzini, F.M., Bonghi, C. \& Tonutti, P. 2009. Postharvest water loss induces marked changes in transcript profiling in skins of wine grape berries. Postharvest Biology and Technology 52: 247-253.

Scalzo, J., Politi, A., Pellegrini, N., Mezzetii, B. \& Battino, M. 2005. Plant genotype affects total antioxidant capacity and phenolic contents in fruit. Nutrition 21: 207-213.

Shan, B., Cai, Y.Z., Sun, M. \& Corke, H. 2005. Antioxidant capacity of 26 spice extracts and characterization of their phenolic constituents. Journal of Agricultural and Food Chemistry 53: 7749-7759.

Wang, C.Y., Chen, C.T. \& Wang, S.Y. 2009. Changes of flavonoid content and antioxidant capacity in blueberries after illumination with UV-C. Food Chemistry 117(3): 426-431 .

Department of Crop Science, Faculty of Agriculture Universiti Putra Malaysia

43400, Serdang, Selangor Darul Ehsan Malaysia

*Corresponding author; email: phebe@upm.edu.my

Received: 15 July 2014

Accepted: 1 April 2015 